\title{
ON FOOT, IN THE SHOPPING CART OR IN THE BUGGY: THE INFLUENCE OF CHILDREN ON SUPERMARKET SHOPPING
}

\section{A pé, no carrinho de compras ou no buggy: a influência das crianças nas compras do supermercado}

Vitor Koki da Costa Nogami

E-mail: vitor.nogami@pucpr.br

Doutor em Administração com ênfase em Marketing pela Universidade de São Paulo; Mestre em Administração pela Universidade Estadual de Maringá; Coordenador do Curso de Administração da Pontifícia Universidade Católica do Paraná, Campus Maringá.

Endereço para contato: Avenida Duque de Caxias, 1020, Zona 7, 87020-025, Maringá, Paraná,

Brasil.

http://orcid.org/0000-0001-5185-731X

Olga Maria Coutinho Pépece E-mail: omcpepece@uem.br

Doutora e Mestre em Administração pela Universidade Federal do Paraná; Professora associada na Universidade Estadual de Maringá http://orcid.org/0000-0002-9155-9285

Juliana Medeiros

E-mail: juliana.medeiros@pucpr.br

Doutora em Administração pela Universidade Federal do Paraná; Mestre em Administração pela Universidade Estadual de Maringá; Diretora na Pontifícia Universidade Católica do Paraná. https://orcid.org/0000-0002-3628-3618

Andres Rodriguez Veloso

E-mail: veloso@usp.br

Livre Docente; Doutor em Administração pela Universidade de São Paulo; Professor Titular na Universidade de São Paulo. http://orcid.org/0000-0003-3037-6773

Artigo recebido em 2 de abril de 2019. Aceito em 29 de outubro de 2020. 


\section{Abstract}

The paper goal is to analyze how the shopping cart strategy can influence the family's buying process when they are with children in supermarket. The literature review addresses both the evolution of supermarket retailing and children's influence on family's decision-making at supermarket. We conduct two researches, first (qualitative) included 12 observations and 7 interviews at one supermarket store, second (quantitative) consisted of a survey at four stores of same supermarket chain with sample of 298 families. The results indicate there mainly findings, (a) parents prefer when children are in shopping cart, (b) children prefer to go in the buggy as there is a funny shopping experience, and (c) when children are walking, they interact more with the products in the supermarket, consequently, its family spend more than had planned. This paper has the following contributions. The paper offers a deeper understanding of how children behave in real settings, providing insights to retail managers on the dynamics of the store. In addition, we offer suggestions to retail managers on how to deploy a cart strategy that has potential to bring superior revenues. Lastly, our findings suggest that in some retail situation, the deployment of certain cart strategies can bring more security to the store.

Keywords: Shopping cart. Supermarket shopping. Consumer behaviour. Retail. Child.

\section{Resumo}

O objetivo do artigo é analisar como a estratégia do carrinho de compras pode influenciar o processo de compra da família quando está com os filhos no supermercado. A revisão da literatura aborda a evolução do varejo de supermercado e a influência das crianças na tomada de decisão da família no supermercado. Realizamos duas pesquisas, a primeira (qualitativa) incluiu 12 observações e 7 entrevistas em uma loja de supermercado, a segunda (quantitativa) consistiu em um survey em quatro lojas de uma mesma rede de supermercados com amostra de 298 famílias. Os resultados indicam como principais achados, (a) os pais preferem quando os filhos estão no carrinho de compras, (b) as crianças preferem ir no carrinho porque há uma experiência de compra divertida e (c) quando as crianças estão caminhando, eles interagem mais com os produtos no supermercado, consequentemente, a família gasta mais do que o planejado. Este artigo tem as seguintes contribuições. $O$ artigo oferece uma compreensão mais profunda de como as crianças se comportam em ambientes reais, fornecendo insights para gerentes de varejo sobre a dinâmica da loja. Além disso, oferecemos sugestões aos gerentes de varejo sobre como implantar uma estratégia de carrinho que tenha potencial para gerar receitas superiores. Por fim, nossos resultados sugerem que, em algumas situações de varejo, a implantação de certas estratégias de carrinho pode trazer mais segurança para a loja.

Palavras-chave: Carrinho de compra. Compra de supermercado. Comportamento do consumidor. Varejo. Crianças.

\section{INTRODUCTION}

When families with children go shopping there is one decision that is made without much attention. Retailers and parents choose if the kid will participate in the buying process (1) on foot, (2) in the shopping cart adapted for children or (3) in a shopping cart formatted as a buggy. This decision will have impact on the level of children participation in the buying process, because children free to wander around will affect the buying process in 
retail environments in several ways (Ebster et al., 2009; Holden, 1983; Veloso et al. 2012). Therefore, the mains objective of this article is to identify how the level of children mobility in supermarkets can influence the family buying process.

The birth rate has been declining in Brazil. In the 70's the birth rate was 5,8, dropping to 2,35 in 2000 and 1,74 in 2013 (Instituto Brasileiro de Geografia e Estatística [IBGE], 2011). Fewer children per family resulted in more money and a bigger disposal of parents on spending money and time with their children (McNeal, 1992). These children are heavily influencing family decision making and buying and this influence tend to grow even more (Dotson \& Hyatt, 2005). The consumption force will affect markets as diverse as home furnishings, automobiles, electronics (Flurry, 2007) and supermarkets (ACNielsen, 2013).

Children over a certain age can assume three different roles as consumers: primary market, when the child him/herself is the consumer; influential market, when the child assumes the role of influencer of the purchase; and future market, when the child is the potential market (McNeal, 1992). Little efforts have been directed to deeply understanding these roles, specially focusing on the behaviour of children in real life environments (Cook, 2008), such as retail stores. Relevant marketing management literature, specifically in textbooks, rarely provides information on children's consumption. Most of early family decision making articles focused only on parents, excluding kids (Mcdonald, 1980), despite Berey and Polay's (1968) early understanding of the importance of children in this process.

The idea that adults, especially parents, are mainly responsible for making buying decisions for children is still out there, leaving children to be mere users (Lawlor \& Prothero, 2011). Despite that, there is a growing debate over the role of children as strong influencers (Carlson \& Grossbart, 1998; Holden, 1983; McNeal, 1969; Mizerski, 1995; Moschis, 1985; RoedderJohn, 1999), whereas the topic has only recently starting appearing in Brazilian literature (Chamie et al., 2012; Veloso \& Campomar, 2012; Veloso et al., 2008; Veloso et al., 2012).

According to surveys conducted by the Brazilian Association of Supermarkets (Associação Brasileira de Supermercados [ABRAS], 2020), the Brazilian supermarket industry has been growing year on year, in may of the present year (2020), sales in the supermarket sector grew $11.93 \%$ compared to the same period in 2019. Revenues from children focused products account for a significant part of those revenues. The market share of products aimed at children has been growing faster than the market share of adult oriented products (ACNielsen, 2013). According to Wilson and Wood (2004) children pay a great influence on supermarket shopping. Thinking about supermarket products that are most related to drink and food, Baldassarre et al. (2013) highlight the importance to study aspects to children's influence on parents to "understand the way marketers have to match little consumers' desires with the necessity of quality required by mothers and fathers" (p. 597). This is relevant because food and drink represents a kind of shopping that calls children's attention by the 
pleasure its consumption brings and calls parents attention because of the influence of these products in health.

Studies about children's influence on family purchase decision found in the theory review focus on different aspects. Kumar (2013) search about product categories Veloso and Campomar, 2012 emphasizes socio economic class, Moschis (1985) debate about the impact of family communication on children consumption socialization and Donohue et al. (2005) discuss the influence of advertising in children's products buying. The present study focusses on the influence of children way of displacement at the supermarket and their persuasion influence on product buying.

Present study intends to analyze the child's role as an influencer in the family purchase decision at supermarket environment (McNeal, 1992). Investigating shopping behavior in this context is also important for children as the primary market, since impulse purchases are targeted at them, and as a market potential, as children can create an emotional bond with stores they attend in childhood.

The format of shopping cart at supermarket arena can directly influence the freedom of child movement that it will generate. In high environmental competition actions target to customer-oriented can be a company differentiator. Retailers can choose not to offer carts that can accommodate children and therefore increasing children mobility in the store. Considering that level of children mobility in a supermarket can affect their behaviour (product requests and direct access to products) and the buying process as a whole, we set out to analyse how the shopping cart strategy applied by supermarkets can influence the family's buying process and consequently their spending behaviour. With the findings, we hope to contribute theoretically to pointing out how children increasingly influence family buying decisions. In managerial terms, we can identify how the methods used to transport children in supermarkets influences family spending, and provide practical tools for supermarket chains to serve better their customers

\section{THE EVOLUTION OF SUPERMARKET RETAIL AND CHILDREN}

As Schor (2004) points out, children have become the epicentre of consumer culture. This reflects on the level of marketing efforts directed to them, boosting their level of brand/ consumer orientation.

According to Kumar (2013) children's influence in the process of family purchase decision depends, among other factors, on the product category. Children's purchase influence is higher when buying low value products and child centric products. Products like treats like ice cream, juice and chocolate children and parents divide the influence in buying process (Kumar), generally products we find on the supermarket. 
McNeal (2007) points that children from two to four years old learn to grab and put products in the shopping cart during supermarket shopping. And this is empowered by what Ebster et al. (2009) found that children request more frequently products that are placed in their eye level and when they are free to move.

For children, going to grocery stores is a funny experience and when they go with their parents to supermarket, parents spend more (Baldassarre et al., 2013). This happens mainly because comparing advertising and children's request parents have hight propensity and good will to satisfy children's request (Baldassarre et al.). This type of behavior refers to what Mikeska et al. (2017) call it a permissive style of socialization for child consumption in which parents are more focused on fulfilling children's wishes. Another influencer of the mothers indulgence specifically regarding the children's purchase orders is related to the mothers' feeling of guilt. Mothers who believe that their children's well-being is primarily their responsibility, tend to buy more products for their children (Valente Batistela-Lima \& Botelho, 2019).

Brazil supermarket managers, worried with this situation and intending to attract more customers identified in the Buggy cart a tool for entertaining children in the store. In figure 1 we present some examples of Buggy Cart's used in Brazil.

\section{Figure 1}

Modern shopping trolleys

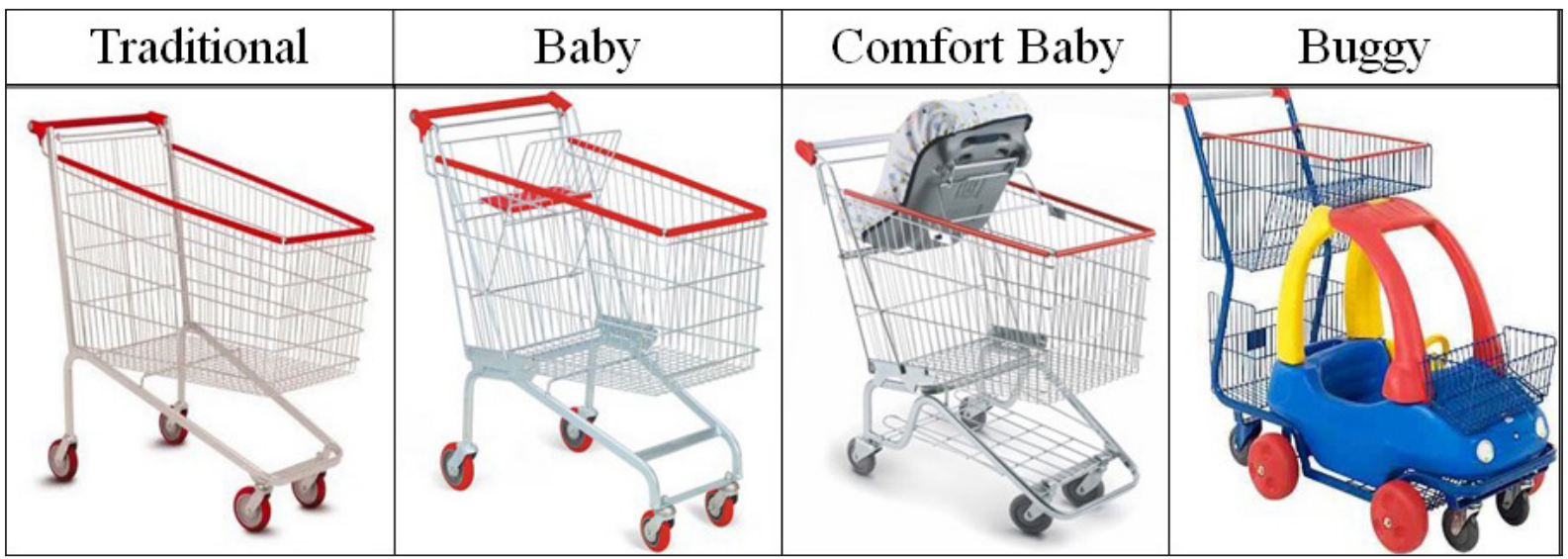

There is no scientific evidence of this, but we suppose that the Buggy cart has a good potential to attract children and parents alike. Children will enjoy riding them and parents will enjoy the opportunity to shop more freely. However, the impact of this strategy on family behavior in retail environments is still unclear. In a French study, Barrey et al. (2010) identified that supermarket chains that focus on children have a certain kind of store loyalty from families that value a more children friendly organized space, therefore we suppose that buggy carts can have similar effects. 


\section{THE CONSUMER BEHAVIOUR OF CHILDREN}

McNeal (1992) proposes that children can assume three roles as consumers: actual buyers, influencers on consumption and future consumers. In consumers' roles, children prefer national brands instead of retailer brand and like brand designer's products (Mowen \& Minor, 2000). In influencer's roles, children will have the most influence when they are the product's users (e.g., vacation) (Limeira, 2008). Engel et al. (1995) points in the United States "a couple whose oldest child is younger than six years old spends ten percent more money in total than the average couple without children" (p. 59). As future consumers Flurry (2007) points "Children are assimilating marketplace knowledge at earlier ages than ever before" (p. 68) and this is an opportunity for marketing professionals to develop brand loyalties at much younger ages.

Children spend most of their daytime playing. There is a consensus about the importance of this to the child's development involving social learning as vocabulary, rules, abilities, and different patterns of interaction that are more appropriate to each "toy" ("considering toys as the support object of the game") (Limeira, 2008, p. 172). Playing is an action mediated by sociocultural context (Limeira). assuming supermarkets as usual places where children's and parents attend together. So, is possible to say that the buggies, in this context, represent the children's toys (Ballantine et al., 2010), like the support object of the "game" called buying and supermarkets represent the learning context of children's socialization into consumption (Mowen \& Minor, 2000).

The process of socialization and learning begins in the infant stage, divided into cognitive development and social learning (Kerrane \& Hogg, 2013; Moschis, 1985).

Piaget (1959) proposes three stages of cognitive development in child children. During the first stage (between 18 months and 2 years) children develop symbolic thought but are still stimulated by visible perceptions, that is, objects that can be observed, touched and felt. This stage in known as "egocentrism" (Montigneaux, 2003). The stage occurs between 2 and 7 to 8 years old. Illustrating this egocentric behavior we have Valkenburg and Cantor (2001) description of children between 2 and 5 years old that cannot use distractive strategies when presented with a tempting stimulus and have great difficulty resisting it what causes "embarrassing situations for parents in the supermarket or toy store" (Valkenburg \& Cantor, p. 65). Usually, around or after the age of 4, children can interact with those around them. Between 7 and 8 years old, children begin to develop more complex thoughts (Piaget, 1959).

According to Selman (1980), the first stage of social learning is occurring between 3 and 6 years old, when the child perceives only her/himself and outside influence is minimum. Between 6 and 8 years, children start becoming aware of information and ideas that are 
different from their own. Subsequently, between 8 and 10 years old, children start to reflect on different opinions. Between 10 and 12, children can connect diverse ideas and at age 12 they start associating these ideas with the society in which they live (McNeal, 1969; RoedderJohn, 1999).

Based on the studies of Piaget (1959) and Selman (1980), Roedder-John (1999) developed a model that divides the socialization of children into three stages: perceptual, analytical and reflective. According to Roedder-John, the perceptual phase, "is characterized by a general focus on the immediate and readily observable sensory features of the market place" ( $p .186$ ), the child sees only visible or observable attributes such as size, shape or colour, influencing its choice between one object and another.

In the analytical phase, changes occur both cognitively and socially. This period comprises key consumer developments in terms of knowledge and skills (Moschis et al., 1984; Roedder-John, 1999). At this stage, the child can make more complex connections, such as identifying the concepts of advertising, brands and prices in the marketplace (Oates et al., 2003). Finally, the reflective phase comprises everything described above, but with a higher capacity for cognition, abstraction and connection of stimuli with their wishes and needs. Table 1 summarizes the stages according to Roedder-John.

\section{Table 1}

Stages of child development

\begin{tabular}{|c|c|c|c|}
\hline Characteristics & $\begin{array}{l}\text { Perceptual stage } \\
\text { (3- } 7 \text { years old) }\end{array}$ & $\begin{array}{l}\text { Analytical stage } \\
\text { (7-11 years old) }\end{array}$ & $\begin{array}{l}\text { Reflective stage } \\
\text { (11-16 years old) }\end{array}$ \\
\hline \multicolumn{4}{|c|}{ Structure of Knowledge } \\
\hline Guidance & Concrete & Abstract & Abstract \\
\hline Focus & Perceptible characteristics & $\begin{array}{l}\text { Functional / Latent Charac- } \\
\text { teristics }\end{array}$ & $\begin{array}{l}\text { Functional / Latent Charac- } \\
\text { teristics }\end{array}$ \\
\hline Complexity & One-dimensional / Simple & $\begin{array}{l}\text { Two or three dimensions / } \\
\text { Contingent }\end{array}$ & Multidimensional \\
\hline Perspective & $\begin{array}{l}\text { Egocentrism (perception of } \\
\text { oneself) }\end{array}$ & $\begin{array}{l}\text { Dual perspective (perception } \\
\text { of oneself }+ \text { others) }\end{array}$ & $\begin{array}{l}\text { Dual perspective in the social } \\
\text { context }\end{array}$ \\
\hline \multicolumn{4}{|c|}{ Decision Making and Strategy of Influence } \\
\hline Guidance & Opportunity & Thoughtful/Attentive & Strategic \\
\hline Focus & $\begin{array}{l}\text { Perceptible characteristics / } \\
\text { Notable Features / Unique } \\
\text { Attributes }\end{array}$ & $\begin{array}{l}\text { Functional / Latent charac- } \\
\text { teristics / Relevant characte- } \\
\text { ristics }\end{array}$ & $\begin{array}{l}\text { Functional / Latent charac- } \\
\text { teristics / Relevant characte- } \\
\text { ristics }\end{array}$ \\
\hline Complexity & Limited & $\begin{array}{l}\text { Two or more attributes / } \\
\text { Increased complexity }\end{array}$ & Multiple attributes \\
\hline
\end{tabular}

Note. Adapted from "Consumer socialization of children: a retrospective look at twenty-five years of research," by D. Roedder-John, 1999, Journal of Consumer Research, 26(3), p. 186.

Note the importance of understanding these stages, both for industries that target children as their primary audience and retail supermarkets strategically place products on 
shelves so that children can choose then. Roedder-John (1999) attempted to categorize these stages more clearly and posited a division (widely quoted in other academic studies) (Moschis et al., 1984; Veloso \& Campomar, 2012), that categorises children as: strategic processors (over 12 years old); indicative processors (from 7-11 years old); and limited processors (younger than 7 years old).

\section{METHOD}

Our research into two studies: study 1 was conducted a preparatory phase; study 2 - we collected from four different supermarkets. Data in both studies within a supermarket chain comprising 35 units distributed in the South, Southeast and Mid-West regions of Brazil. The managers and employees were aware that the survey was being conducted and informed of the methodological procedures employed.

\subsection{STUDY 1}

\subsubsection{Methodological procedures}

In study l, we conducted qualitative study through interviews and observations. Little is known about the buying behaviour of children relevant to the different shopping trolleys in Brazil and following Atkin (1978) suggestion about the accurate assessment provided by observations. The main purpose was to identify how is the interaction and influence among parents and child(ren) during the buying process. This generated propositions that we tested with study. We began study 1 interviewing the manager responsible for the supermarket. The aim was to uncover essential information about children and trolley use. We focused on how trolley use could influence family buying process. After that, we performed on-site observations in supermarkets (parents and children). Collecting empirical data on-site presents many difficulties and when children are the object of the collection, this difficulty increases; observation is an alternative method employed to access empirical data with this audience (Baxter, 2012; Nairn \& Clarke, 2012; Veloso et al., 2008).

We sought to observe how children interact with their parents and the products on the supermarket shelves (Lawlor \& Prothero, 2011). We observed: 1) the transportation mode (e.g., on foot, in trolley). Second, the volume of products that children tried to take and buy depended on the transportation mode. Third, the time spent on the supermarket of families that took their children. Finally, the parents' mood of the supermarket. Thus, still within study l, we conducted interviews with some of observed parents to gain more insight. Children over 
seven years old rarely use buggies, mainly because they do not fit it anymore. We used this information to participate of the research. The minimum age was not defined considering that some children grow up fasten then others, but we focused on children that could take products by their own and interact with the supermarket shelves.

All observations using and audio diary technique. The observer verbally describing and recording what she saw. In total, 12 recordings were collected, comprising 28 minutes of audio and 14 pages of transcript. Once they had finished shopping, the observer would talk to the person responsible for the child, confirming the child's age, providing information about the survey, and requesting an interview.

In total, 7 interviews were conducted. We recorded the interviews with permission of the respondents and transcribed for further analysis. At this stage, the data collection instrument was a semi-structured script elaborated to lead the conversation by asking openended questions. In this way, the instrument was flexible and adaptable to the direction taken by the interview (Belk, 2006). In general, the questions investigated the preference of the type of mobility of parents and children, the relationship of the type of mobility with parents and children, the advantages and disadvantages of each type of mobility, all the related products choices and families decision purchase. The interviews totalled 88 minutes of recording and 18 pages of transcript. Both audio recordings and interviews have undergone content analysis to organise the data and subsequent presentation of results (Bardin, 1977;

Denzin \& Lincoln, 2005).

The data collection for study 1 occurred over a two-week interval, during four different visits to one of the supermarkets pertaining to the previously mentioned chain. The visits occurred on both regular trading days and on specific days offering reduced prices in specific product categories such as meat and vegetables. At this stage, we collected data in one supermarket only.

\subsubsection{Results}

When children are present, shopping trolleys become essential in that they provide fun for the children and convenience for their parents, but the trolley has become an attraction for children in the supermarkets, as stated by the manager responsible for the supermarket where study 1 was conducted. He informed that he has requested more buggies, because he realized that when the entire 'fleet' was occupied, many of these parents waited for one to become available before starting their shopping. This perception was confirmed in the interviews with interviewee parents stating they would wait for a buggy to become available or would enter the supermarket but go back to the car park to find one available. 
However, the buggy is not always the parents' preference and some of them end up taking two trolleys - the buggy and the traditional one - or they do not take the buggy due to reduced space to put the groceries. "Father 1: You have to get another trolley, because the groceries won't fit in the buggy. The buggy is more for him to play" (personal communication, March, 2012). "Mother 1: We usually get the buggy because of her, but I prefer the traditional trolley" (personal communication, March, 2012).

We noted that for parents the buggy is not practical for transporting the shopping. In addition to the fact that the space provided by the buggy is limited, some mothers also stated they do not put their children in the buggy because they are very active and do not stay still in the trolley easily, claiming this enables them to stray from view and pick up the products from the shelves.

From the observations and interviews, we noted that parents often place their children in the traditional trolleys, so they ask fewer products. This is an alternative employed by parents to better control children and restrict their contact with the products on the shelves. This conclusion was reached from the interviews and observations.

Mother 5: I grab the traditional trolley, because he runs away when he's in the buggy. I don't even let him see it but he runs from the trolley and goes after the buggy so where there's nothing else for it, I end up taking the buggy. In here (traditional trolley) he behaves more, he's quieter.

Recording 1: Child enters the supermarket with parents and older brother. Parents put the child in the traditional trolley and go straight to the shelves of essential products, always leaving the trolley with the child in the middle of the aisle where the child is not able to reach the products on the shelves. When they pass a pile of stacked products, where the child could reach the product, the child reached out and grabbed a packet of grated cheese. The father took it out of the child's hand and returned the product. Constantly, at least one family member interacts with the child, either his father or brother. After going through the toiletries, they went straight to the cashier to pay for the products, without passing by the shelves displaying non-necessary goods. (personal communication, March, 2012).

Parents prefer to take their kids in the traditional trolley because it allows them better control to their actions. During the observations and interviews it was noted that when children are in the traditional trolley, they interact less with the products than when they are in the buggy, as seen below:

Recording 2: The father pushes the boy in the buggy, and when they go through the cereals section the child leaves the trolley and goes straight to the small packages within its reach and grabs a Snow Flakes cereal with a teddy bear on the box. 
Recording 6: The child is playing with the steering wheel of the buggy without interacting with the products, but when the parents come to the shelves with biscuits, the child leaves the trolley and goes straight to the biscuits.

Mother 3: When she is in the buggy, she gets out to touch things, sometimes she is in the buggy playing, at other she is touching things. (personal communication, March, 2012).

When children are in the buggy and find something interesting, they leave the buggy and go straight to the shelves without any difficulty. When children see a product that interests them, their willingness to interact with the product is stronger than the desire to play with the buggy, making them turn their attention to the product and so climb out of the buggy to pick it up.

On the other hand, when parents take children on foot, they argue that the interaction with the product is even higher, because there is no way to hold the child. This was also observed during our visits to the supermarket. When walking with parents, children are free; they walk and run through the aisles, touching everything they see. This can be seen in the comments:

Mother 3: She simply won't stay in the seat. I put her there, but she doesn't stay still. She likes to walk around, she likes to touch, to see up close.

Mother 5: In here (traditional trolley) he behaves more, he is quieter, but when he is out of the trolley he runs away, then he picks up everything, even though he is very obedient there's no avoiding it, he grabs everything. (personal communication, March, 2012).

As stated by Roedder-John (1999), children often touch the product because they are attracted by its physical and visible characteristics, sometimes they do not even know what it is or what it does, but they transform that into play. In one of the observations, a girl grabbed the stick of a mop and pretended she was playing the guitar. In such cases, rarely are children aware of the practical purpose for which the product was designed, but they still interact, giving a new meaning to the product and transforming it into a toy.

When they discover it is useful to them, or something they like, children grab the product and take it to their parents to either ask permission or simply to place it in the trolley. The fact that they place it in the trolley may be due to their learning process to become consumers and a consequence of their development in that they see their parents removing products from shelves and putting them in the trolleys and subsequently imitate this action (Moschis et al., 1986; Roedder-John, 1999; Veloso et al., 2012). Thus, we developed six proposition addressing the results obtained from the study 1 interviews and observations.

\section{Pl: Buggy vs. Traditional}


Pla: When children are in the buggy, they interact more with the products than when they are in the traditional trolley.

Plb: When children are in the buggy, they influence their parents to spend more than when they are in the traditional trolley.

\section{P2: Walking vs. Buggy}

P2a: When children are walking, they interact more with the products than when they are in the buggy.

P2b: When children are walking, they influence their parents to spend more than when they are in the buggy.

\section{P3: Walking vs. Traditional}

P3a: When children are walking, they interact more with the products than when they are in the traditional trolley.

P3b: When children are walking, they influence their parents to spend more than when they are in the traditional trolley.

Using the results of Study 1 and the propositions created, we conducted a second study (study 2). A survey was conducted with parents as recommend McNeal (1992), who pointed out that it is often difficult for children below 8 . This stage was to complement and provide more depth to study 1 and verify propositions.

\subsection{STUDY 2}

\subsubsection{Methodological Procedures}

We collected from four stores belonging to the same supermarket chain as in Study 1. We chose these stores base on two criteria: (1) having a high daily turnover of customers; and (2) providing the buggy for consumers. Given that a high daily turnover of customers was one of the criteria for defining which supermarkets would be the target of data collection, the management of the supermarket chain in which we collected data informed that: the units with this profile are the units with the highest concentration of consumers from social classes B2, C1 and C2 (Associação Brasileira de Empresas de Pesquisa [ABEP], 2008), because this profile when compared to classes $\mathrm{Al}, \mathrm{A} 2$ and $\mathrm{B} 1$ visits the supermarket more frequently and spends less on average. Also, the consumption of these classes, from 2004 on, now represents $53 \%$ of total food consumption in Brazil (Latin Panel, 2004).

The survey consisted of a convenience sample of 298 valid cases, 114 cases had the child using a traditional trolley, 76 in the buggy; 108 walking. We sought a level of parity between 
the three situations. We surveyed parents as they stood in the checkout line or immediately after payment at the cashier. The collection took place usually between 5:00 pm and 8:00 pm, a period in which there was a higher flux of families with children in the supermarkets. The questionnaire was structured based on the results of study 1 and underwent three pretests. Stage 2 data over 3 months. The questionnaires were not self-administered and thus collection required more time and effort. Descriptive statistics, paired t-test and chi-square were used to analyse the data. The next section presents the results of study 2 .

\subsubsection{Results}

Table 2 categorises respondents with respect to profile, frequency and choice of trolley. When approached to answer the questionnaire, of those families when both the father and mother were present in the supermarket with their children, the majority of respondents who opted to participate were mothers. The age of the children was also controlled, however, since many children aged 6 or older do not fit into the trolleys, the sample of children aged between 6 and 7 was smaller.

\section{Table 2}

Characteristics of the Families Interviewed

\begin{tabular}{|c|c|c|c|c|c|}
\hline $\begin{array}{l}\text { Respondent relation } \\
\text { type }\end{array}$ & $\%$ & $\begin{array}{l}\text { Frequency of visits to the } \\
\text { supermarket }\end{array}$ & $\%$ & $\begin{array}{l}\text { Situation of the child at Time } \\
\text { of Purchase }\end{array}$ & $\%$ \\
\hline Mother & 62.4 & More than once a week & 54.4 & Traditional & 38.3 \\
\hline Father & 26.5 & Once a week & 31.9 & Buggy & 25.5 \\
\hline Grandmother & 6.7 & Once every two weeks & 9.7 & Walking & 36.2 \\
\hline Others & 4.4 & Once every three weeks & 2.0 & Preference of the Child & $\%$ \\
\hline Age of Child & $\%$ & Once a month & 2.0 & Traditional & 24.2 \\
\hline 2 years old & 18.1 & $\begin{array}{l}\text { Frequency going with } \\
\text { children }\end{array}$ & $\%$ & Buggy & 50.3 \\
\hline 3 years old & 28.2 & Always & 57.0 & Walking & 25.5 \\
\hline 4 years old & 21.8 & Often & 15.4 & Preference of the Respondent & $\%$ \\
\hline 5 years old & 17.1 & Sometimes & 18.5 & Traditional & 48.7 \\
\hline 6 years old & 10.1 & Rarely & 8.4 & Buggy & 29.2 \\
\hline 7 years old & 4.7 & Never & 0.7 & Walking & 22.1 \\
\hline
\end{tabular}

Note. $\mathrm{N}=298$ (Gender of child: $53.4 \%$ male; $46.6 \%$ female).

Most respondents visit the supermarket once a week $(86.3 \%)$ and when asked being accompanied by their children when shopping, many stated that they are forced to bring their children due to lack of a guardian at home, thus confirming the change in lifestyle of modern the current society in which both fathers and mothers work away from home, as indicated by 
IBGE (2011). It is worth noting that most respondents' social class profile falls into that of B2, $\mathrm{Cl}$ and $\mathrm{C} 2$, as informed by the supermarket chain's management regarding the predominant profile of consumers who frequent the units at which the data were collected. This is contrary to individuals considered as being of classes $\mathrm{Al}$ and $\mathrm{A} 2$ and are thereby financially able to employ housemaids or nannies with whom they can leave their children, if they so choose, when they go to the supermarket.

Regarding the choice of the trolley, most children prefer the buggy (50.3\%). These data converge with the results of study 1 , which show that children prefer the buggy, because they see being in the supermarket as a moment of fun and entertainment. They interact with the steering wheel; they reproduce the sound of the car and even the horn. With respect to the respondents' (mothers, fathers and others) preferred model, most answered the traditional trolley $(48.7 \%)$. This is also corroborated by study $\mathrm{l}$, wherein the parents interviewed stated the traditional trolleys offer greater control over their children, restricting their freedom to run amok and grab products from the shelves, which consequently allows greater attention to the shopping and more efficiency. Walking is the option least preferred by both parents (in that it reduces control over their children) and children because it deprives them of the fun they get from the buggy.

Table 3 shows the mean values of the two dependent variables of the study: 'interacting more with the products on the shelves' and, making parents 'spend more than planned.' Both variables were measured according to the 5-point Likert scale. According to the results, when children are walking, they interact most with the products and have most influence on unplanned purchases, thus confirming the literature used (McNeal, 1969; Roedder-John, 1999; Veloso et al., 2012). To statistically confirm whether this result is significant, the propositions were verified through paired t tests, as all respondents belong to the same sample.

\section{Table 3}

Average of Dependent Variables and Paired t Test

\begin{tabular}{|c|c|c|c|c|c|c|}
\hline \multirow{2}{*}{\multicolumn{3}{|c|}{ Interacts more with the product }} & \multirow{2}{*}{\multicolumn{2}{|c|}{ Buggy vs. Traditional }} & \multirow{3}{*}{$\begin{array}{c}\begin{array}{c}\text { Difference of } \\
\text { Average }\end{array} \\
.233\end{array}$} & \multirow{3}{*}{$\begin{array}{c}\text { Sig. } \\
.133\end{array}$} \\
\hline & & & & & & \\
\hline Traditional & Buggy & Walking & Hla & $\begin{array}{l}\text { Interacts more with the } \\
\text { product }\end{array}$ & & \\
\hline 3.079 & 2.852 & 4.228 & $\mathrm{HIb}$ & Spends more than planned & .156 & .134 \\
\hline \multicolumn{3}{|c|}{$\begin{array}{c}\text { Makes parents spend more than } \\
\text { planned }\end{array}$} & \multicolumn{2}{|r|}{ Walking vs. Buggy } & & \\
\hline Traditional & Buggy & Walking & $\mathrm{H} 2 \mathrm{a}$ & $\begin{array}{l}\text { Interacts more with the } \\
\text { product }\end{array}$ & 1.383 & $.000^{* *}$ \\
\hline \multirow[t]{4}{*}{3.106} & 2.938 & 3.628 & $\mathrm{H} 2 b$ & Spends more than planned & .699 & $.000^{* *}$ \\
\hline & & & \multicolumn{2}{|r|}{ Walking vs. Traditional } & & \\
\hline & & & $\mathrm{H} 3 \mathrm{a}$ & $\begin{array}{l}\text { Interacts more with the } \\
\text { product }\end{array}$ & 1.162 & $.000^{* *}$ \\
\hline & & & $\mathrm{H} 3 \mathrm{~b}$ & Spends more than planned & .529 & $.000^{* *}$ \\
\hline
\end{tabular}

Note. ${ }^{* *} p<.01$ (significance). 
Table 3 shows the analyses of the proposition. When comparing the averages of variables; 'greater interaction with the product' and 'greater influence on unplanned purchases,' between the buggy vs. traditional trolley, the results do not show sufficient significance, in other words, they fail to confirm Hla and HIb. Conversely, when comparing the dependent variables in situations; 'walking vs. buggy', and 'walking vs. traditional trolley', significant results were obtained. When children are walking, they interact much more with the products and influence their parents to make more unplanned purchases than when they are in the buggy or when they are in the traditional trolley; thereby confirming $\mathrm{H} 2 \mathrm{a}, \mathrm{H} 2 \mathrm{~b}, \mathrm{H} 3 \mathrm{a}, \mathrm{H} 3 \mathrm{~b}$. According to the differences of averages, there is no relationship of dependence between interacting more with the products and influencing the purchase of unplanned products; however, when children are walking, there is a clear opportunity to increase the average sums spent by each family in the supermarket.

To provide more weight to the results found, we also performed a chi-square test between the three situations studied with the dependent variable: "have you bought anything that was not planned" (yes/no). The result indicates that of the 298 valid cases, 203 families made unplanned purchases that were influenced by children. The level of significance for the test $(p=0.008)$ indicates that when the child is walking, there is a higher probability between the three types of mobility. In other words, this analysis strengthens the previous results (Table 4 indicates absolute numbers).

Table 4

Have you bought anything that was not planned

\begin{tabular}{ccccc}
\hline & Traditional & Buggy & Walking & Total \\
\hline Yes & 78 & 42 & 83 & 203 \\
\hline No & 36 & 34 & 25 & 95 \\
\hline Total & 114 & 76 & 108 & 298 \\
\hline Relative Risk & 1.01 & 0.58 & 1.55 & \\
\hline
\end{tabular}

By analysing the relative risk of each situation, it is possible to state that when children are walking, the probability of influencing an unplanned purchase is $55 \%$ higher than that of non-influencing. But when children are in the traditional trolley, this probability drops to $1 \%$. On the other hand, when children are in the buggy, it is most likely that they do not influence an unplanned purchase $(-42 \%)$. The fact that children are interacting with the buggy holds their attention and calms them, thus avoiding situations of conflict, insistence, crying and discomfort with their parents when insisting to buy products. 
The results of tables 2 and 3 show that the buggy makes children interact less with the products and makes parents spend less on unplanned purchases. But when children are walking, there is greater interaction and the likelihood of spending more is higher.

\section{DISCUSSION AND FINAL CONSIDERATIONS}

Our goal was to identify how the methods used to transport children in supermarkets influences family spending. The study allowed us to understand and describe the relationship between the means of mobility used by children and their interaction with the products in the supermarket and the increase, or otherwise, in the volume of unplanned purchases resulting from the type of mobility used.

Results allowed us to identify that the type of mobility used by children influences their interaction with the products in the supermarkets, in addition to generating an increase in the purchase of unplanned items. Therefore, when children are walking, they interact more with the products by grabbing them and subsequently asking their parents to buy them. This type of mobility results in increased volume of purchases by parents regarding the items desired by children. However, despite being granted purchase of the objects requested and having greater autonomy to access the products, this means of mobility is preferred neither by the children, who generally prefer to ride a buggy; nor by their parents, who mostly prefer to put children in traditional trolleys, which provide parents with greater control over them.

Therefore, if the buggy does not increase items purchased for children, as occurs when they are walking, and furthermore represent an additional cost to supermarkets; and if parents prefer to put them in the traditional trolley, we are left with the question: by whom and for what reason is the strategy of the buggy implemented?

Although parents prefer to use the traditional trolley for their functionality (e.g., more space for products, greater control over their children, many parents give in to their children's demands and choose the buggy. This fact reinforces the redefinition of the act of buying general consumer goods resulting from the new lifestyle of families. With the insertion of women into the labour market and the daily activities that increasingly occupy people's lives, the time available for children.

As a way to resolve this inconvenience, many relatives, both parents and grandparents, have started taking children along to do domestic shopping as a way to spend more time with them. As we have seen, this activity currently means "leisure". What may previously have been viewed merely as an obligation to shop for general consumer goods today may be seen as an opportunity to stimulate interaction between parents and children or grandparents and grandchildren. In this context, children's demands are often met. Therefore, starting with 
the choice of trolley, children exert influence on those who take them to the supermarket, even if the trolley is not their preferred choice (Moschis, 1985).

Still from the perspective of children's guardians, especially their parents, the buggy can be used as a strategy to entertain children, which in turn enables more efficiency when shopping for household goods. The results of tables 4 and 5, which show that children interact less with the products when they are in the buggy than when they are walking. However, although children become more distracted with the buggy, it does not distract them to the point where they fail to see the products that interest them; as demonstrated in the results of observations and respondents who stated that when children see something that interests them, they get out of the buggy and pick up the product.

Therefore, the role of the buggy is that of strategic distraction so that: children do not go running around the supermarket worrying and stressing parents and take the focus out of the purchases, but they do not necessarily prevent children from asking more products than those listed for that shopping. Supermarkets can offer different types of buggies to awaken children's desire to use one every time that go to the supermarket. In relation to parents, provide safety devices for the child within the buggy is also a form that can be used in ads.

The buggy is useful for parents, grandparents and other adults who need or choose to bring children with them when shopping for household goods. The supermarkets, in that it provides entertainment for children and greater peace of mind for parents when shopping and enables focus on buying the necessary items or rushing the supermarket experience due to the irritation of the children in the supermarket. This possibility can make certain consumers opt to buy at supermarkets that offer the buggy.

Given the increased number of items purchased by parents when children are free to walk around the supermarket, we suggest supermarket owners provide smaller 'childsize' traditional trolleys to push while their parents do the shopping with the traditional trolleys available in the supermarkets. In this situation, children would control their own trolley, mimicking their parents' behaviour, picking up products from the shelves and putting them in the trolley, whereby learning how to be consumers, and subsequently influencing the average amount spent by families in the supermarket.

Since products are already strategically positioned within reach of children on the shelves, this situation will allow children to interact with the products while remaining calm and under parent control when they are walking. This situation could be favourable both for children and their parents, and especially for supermarkets. Children may continue to consider this moment as entertaining and fun as with the buggy but will also be transiting in the supermarket aisles having access to the products and reproducing the behaviour of their parents. 
Our findings offer two contributions. First, we extend a deeper understanding on how children behave in real settings providing retail managers on the dynamics of the store. This contribution focus specialty on child consumer behavior literature. Second, we offer retail managers on how to deploy a cart strategy that has potential to bring superior revenues. This finding can guide marketing management in supermarket companies.

Our results are limited by the fact that only one supermarket chain was chosen by convenience, with consumers predominantly from classes $\mathrm{B} 2, \mathrm{Cl}$ and $\mathrm{C} 2$, not allowing an analysis of the influence of the type of mobility in the buying behaviour of children from higher economic classes; and for not having an equal number of respondents from the three types of mobility analysed. In addition, we did not take to account the influence of the number of children in family on the supermarket child buying behaviour, for example, when a family take only one child if they buy more things for the child then parents who has two or more children. Another limitation was interviewees did not feel comfortable in telling how much they spend with children's influence and the total amount spent on family's supermarket purchase.

As potential future studies, we suggest assessment of which type of product/ packaging attracts children's attention more in supermarkets. In terms of different products, even if not directly targeted towards children, most influence their parents to buy. In terms of the influence of advertising and television cartoons on the attractiveness of supermarket products for children we suggest strategies should focus influence in parents supermarket purchase, if it is when children put products into the trolley, or when they present insistent verbal requests.

\section{REFERENCES}

ACNielsen. (2013). População infantil diminui, mas ganha importância. http://www.acnielsen. com.br

Associação Brasileira de Empresas de Pesquisa. (2013). Critério de classificação econômica Brasil. http://www.abep.org/novo/Content.aspx?ContentlD=301

Associação Brasileira de Supermercados. (2020). Aumento do faturamento dos supermercados. https://www.abras.com.br/economia-e-pesquisa/indice-de-vendas/indice-do-mes/

Atkin, C. A. (1978, October). Observation of parent-child interaction in supermarket decision make. Journal of Marketing, 42(4), 41-45. 
Ballantine, P. W., Jack, R., \& Parsons, A. G. (2010). Atmospheric cues and their effect on the hedonic retail experience. International Journal of Retail \& Distribution Management, $38(8), 641-653$.

Baldassarre, F., Campo, R., \& Falcone, A. (2016). Food for kids: How children influence their parents purchasing decisions. Journal of Food Products Marketing, 22(5), 596-609.

Bardin, L. (1977). L'analyse de contenu. Presses Universitaires de France.

Barrey, S., Baudrin, M., \& Cochoy, F. (2010). Young consumers: Insight and ideas for responsible marketers emerald article: From fun foods to fun stores. Young Consumers, 11(2), 138-147.

Baxter, S. (2012). Exploring children's attitudes towards research participation. The Market Research Society, 54(4), 455-464.

Belk, R. W. (2006). Handbook of qualitative research methods in marketing. MPG Books.

Berey, L. A., \& Pollay, R. W. (1968). The influencing role of the child in family decision making. Journal of Marketing Research, 5(2), 70-72.

Carlson, L., \& Grossbart, S. (1988). Parental style and consumer socialization of children. The Journal of Consumer Research, 15(1), 77-94.

Chamie, B. C., Ikeda, A. A., \& Parente, J. (2012). Atmosfera de loja como um elemento da estratégia varejista. Revista Administração em Diálogo-RAD, 14(1). http://revistas.pucsp. $\mathrm{br} /$ index.php/rad/article/view/10178/7644

Cook, D. (2008, October). The missing child in consumption theory. Journal of Consumer Culture, 8(2), 219-243.

Denzin, N. K., \& Lincoln, Y. S. (2005). Handbook of qualitative research. Sage.

Donohue, T. R., Henke, L. L., \& Donohue, W. A. (2005). Do kids know what tv commercials intend? Journal of Advertising Research, 20(5), 51-57.

Dotson, M. J., \& Hyatt, E. M. (2005). Major influence factors in children's consumer socialization. Journal of Consumer Marketing, 22(1), 35-42.

Ebster, C., Wagner, U., \& Neumueller, D. (2009). Children's influences on in-store purchases. Journal of Retailing and Consumer Services, 16(2), 145-154. 
Engel, J., Blackwell, R., \& Miniard, P. (1995). Consumer Behavior. Dryden.

Flurry, L. A. (2007). Children's influence in family decision-making: Examining the impact of the changing American family. Journal of Business Research, 60(4), 322-330.

Holden, G. D. (1983). Avoiding conflict: Mothers as tacticians in the supermarket. Child Development, 54, 233-240.

Instituto Brasileiro de Geografia e Estatística. (2011). Censo 2010.

Kerrane, B., \& Hogg, M. K. (2013). Shared or non-shared? Children's different consumer socialization experiences within the family environment. European Journal of Marketing, $47(3-4), 506-524$.

Kumar, S. (2013). Children influence in the process of family purchase decision for high, low and child-Centric products. Researchers World, 4(3), 34.

Lawlor, M-A., \& Prothero, A. (2011). Pester power - A battle of wills between children and their parents. Journal of Marketing Management, 27(5-6), 561-581.

Latin Panel. (2004). Consumidores de baixa renda: Onde estão, quem são e o que consomem. www.latinpanel.com.br

Limeira, T. (2008). Comportamento do consumidor brasileiro. Saraiva.

McDonald, G. W. (1980). Family power: The assessment of a decade of theory and research, 1970-1979. Journal of Marriage \& Family, 42(11), 841-854.

McNeal, J. U. (1969). The child consumer: A new market. Journal of Retailing, 45(2), 15-22.

McNeal, J. U. (1992). Kids as customers - a handbook of marketing to children. Lexinton Books.

McNeal, J. (2007). On becoming a consumer. Routledge.

Mikeska, J., Harrison, R. L., \& Carlson, L. (2017). A meta-analysis of parental style and consumer socialization of children. Journal of Consumer Psychology, 27(2), 245-256.

Mizerski, R. (1995). The relationship between cartoon trade character recognition and attitude toward product category in young children. Journal of Marketing, 59(4), 58-70. 
Montigneaux, N. (2003). Público alvo: Crianças. Negócio Editora.

Moschis, G. P. (1985). The role of family communication in consumer socialization of children and adolescents. Journal of Consumer Research, 11(4), 898-913.

Moschis, G. P., Moore, R. L., \& Smith, R. B. (1984). The impact of family communication on adolescent consumer socialization. Advances in Consumer Research, 11(1), 314-319.

Moschis, G. P., Prahasto, A. E., \& Mitchell, L. G. (1986). Family communication influences on the development of consumer behavior: Some additional findings. Advances in Consumer Research, 13(1), 365-369.

Mowen, J., \& Minor, M. (2000). Consumer behavior. Prentice Hall.

Nairn, A., \& Clarke, B. (2012). Researching children: Are we getting it right? The Market Research Society, 52(2), 177-198.

Oates, C., Blades, M., Gunte, B., \& Don, J. (2003). Children's understanding of television advertising: A qualitative approach. Journal of Marketing Communication, 9(2), 59-71.

Piaget, J. (1959). Linguagem e o pensamento da criança. Fundo da Cultura.

Roedder-John, D. (1999). Consumer socialization of children: A retrospective look at twenty-five years of research. Journal of Consumer Research, 26(3), 183-213.

Selman, R. L. (1980). The growth of interpersonal understanding. Academic Press.

Schor, J. (2004). Born to buy. Scribner.

Valente Battistella-Lima, S., \& Botelho, D. (2019). A relação entre a culpa das mães e suas decisões de consumo. Revista Brasileira de Marketing, 18(2), 171-197.

Veloso, A. R., \& Campomar, M. C. (2012). Segmentation and positioning in the Brazilian kids market: A case study on the bottom of the pyramid. Revista Administração em Diálogo, $14(1), 122-153$.

Veloso, A. R., Hildebrand, D. F. N., \& Campomar, M. C. (2012). Marketing e o mercado infantil. Cengage Learning. 
Veloso, A. R., Hildebrand, D. F. N., Dare, P. R. C., \& Campomar, M. C. (2008). A criança no varejo de baixa renda. Revista de Administração de Empresas, 7(2), 1-26.

Valkenburg, P. M., \& Cantor, J. (2001). The development of a child into a consumer. Journal of Applied Developmental Psychology, 22(1), 61-67.

Wilson, G., \& Wood, K. (2004). The influence of children on parental purchases during supermarket shopping. International journal of consumer studies, 28(4), 329-336.

\section{Como citar este artigo:}

\section{ABNT}

NOGAMI, Vitor Koki da Costa; PÉPECE, Olga Maria Coutinho; MEDEIROS, Juliana; VELOSO, Andres Rodriguez. On foot, in the shopping cart or in the buggy: the influence of children on supermarket shopping. RACE, Revista de Administração, Contabilidade e Economia, v. 19, n. 3, p. 419-440, set./dez. 2020. Disponível em: http://editora.unoesc.edu.br/ index.php/race. Acesso em: dia/mês/ano.

\section{APA}

Vitor Koki da Costa Nogami, V. K. C., Pépece, O. M. C., Medeiros, M., \& Veloso, A. R. (2020). On foot, in the shopping cart or in the buggy: The influence of children on supermarket shopping. RACE, Revista de Administração, Contabilidade e Economia, 19(3), 419-440. http://editora.unoesc.edu.br/index.php/race 